DOI: https://doi.org/10.31933/jimt.v2i3 Received: 21 November 2020, Revised: 25 Desember 2020, Publish: 15 Februari 2021

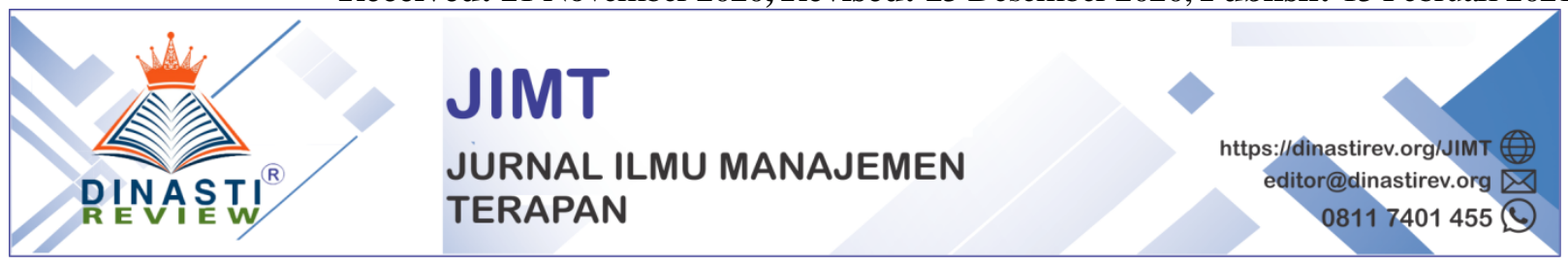

\title{
PERBANDINGAN ANALISIS RASIO KEUANGAN PT. INDONESIA PONDASI RAYA TBK. DENGAN TOTAL INDUSTRI SUB SEKTOR BUILDING CONSTRUCTION PERIODE 2014 - 2019
}

\author{
Gunaldi Gunaldi \\ ${ }^{1)}$ Magister Management Universitas Mercu Buana, Jakarta, gun.adek@yahoo.co.id, \\ gun.adek08@gmail.com
}

Corresponding Author: Gunaldi Gunaldi

Abstrak: Tujuan penelitian ini untuk menilai kinerja PT. Indonesia Pondasi Raya Tbk. dibandingkan dengan industri sub sektor building construction dari tahun 2014 sampai dengan tahun 2019 dengan menggunakan analisis rasio keuangan perusahaan, yaitu rasio likuiditas, rasio aktivitas, rasio profitabilitas dan rasio solvabilitas. Sumber data yang digunakan dalam penelitian ini adalah data sekunder yang berasal dari laporan keuangan yang diterbitkan perusahaan. Perusahaan sub sektor building construction berjumlah 17 perusahaan, tetapi perusahaan yang mempunyai data laporan keuangan yang lengkap dari tahun 2014 sampai dengan 2019 hanya ada 12 perusahaan. Nilai total industri pada makalah ini merupakan penjumlahan dari 12 perusahaan tersebut.

Kata Kunci : Laporan keuangan, Analisis Rasio, Kinerja Perusahaan

\section{PENDAHULUAN}

Menurut Myer dalam bukunya Financial Statement Analysis mengatakan bahwa yang dimaksud dengan laporan keuangan adalah : "Dua daftar yang disusun oleh Akuntan pada akhir periode untuk suatu perusahaan. Kedua daftar itu adalah daftar neraca atau daftar posisi keuangan dan daftar pendapatan atau daftar rugi-laba, dimana neraca menunjukkan atau menggambarkan jumlah aktiva, hutang dan modal dari suatu perusahaan pada tanggal tertentu, sedangkan Perhitungan (laporan) rugi-laba memperlihatkan hasil-hasil yang telah dicapai oleh perusahaan serta biaya yang terjadi selama periode tertentu.

Laporan keuangan merupakan alat yang sangat penting untuk memperoleh informasi sehubungan dengan posisi keuangan dan hasil-hasil yang telah dicapai oleh perusahaan yang bersangkutan. Data keuangan tersebut akan lebih berarti bagi pihak-pihak yang berkepentingan apabila data tersebut diperbandingkan untuk dua periode atau lebih, dan dianalisa lebih lanjut sehingga dapat diperoleh data yang akan mendukung keputusan yang akan diambil.

Agar laporan keuangan menjadi lebih berarti sehingga dapat dipahami dan dimengerti oleh berbagai pihak, perlu dilakukan analisis laporan keuangan. Bagi pihak pemilik dan manajemen, tujuan utama analisis laporan keuangan adalah agar dapat mengetahui posisi keuangan perusahaan 
saat ini. Dengan mengetahui posisi keuangan, setelah dilakukan analisis laporan keuangan secara mendalam, akan terlihat apakah perusahaan dapat mencapai target yang telah direncanakan sebelumnya atau tidak.

PT. Indonesia Pondasi Raya (Indopora) Tbk. adalah Emiten yang bergerak di bidang konstruksi pondasi, dinding penahan tanah, perbaikan tanah dan pengujian tiang. Sebagai perusahaan yang sebagian sahamnya dimiliki oleh public tentunya kinerja keuangan perusahaan akan menjadi sorotan. Oleh karena itu peneliti tertarik untuk melakukan penelitian lebih lanjut dengan melakukan analisis kinerja keuangan pada PT. Indopora Tbk yang akan dibandingkan dengan ratarata industri sub sektor building construction.

\section{Rumusan Masalah}

Berdasarkan latar belakang yang diuraikan diatas, maka rumusan masalah pada penelitian ini adalah bagaimana kinerja keuangan PT. Indonesia Pondasi Raya (Indopora) Tbk dibandingkan dengan rata-rata industri sub sektor building construction dari tahun 2014 sampai dengan tahun 2019.

\section{Tujuan dan Manfaat Penelitian}

1. Tujuan Penelitian

Untuk menilai kinerja keuangan PT. Indonesia Pondasi Raya Tbk.

2. Manfaat Penelitian

a. Bagi peneliti, dapat menambah ilmu pengetahuan dan wawasan mengenai kinerja keuangan dalam suatu perusahaan.

b. Bagi akademisi, sebagai bahan referensi dalam melakukan penelitian ulang mengenai kinerja keuangan.

c. Bagi perusahaan, hasil penelitian ini diharapkan dapat memberikan masukan bagi perusahaan yang bersangkutan dalam kaitannya dengan kinerja keuangan.

\section{Landasan Teori}

1. Pengertian Laporan Keuangan

Dalam pengertian yang sederhana laporan keuangan adalah laporan yang menunjukkan kondisi keuangan perusahaan pada saat ini atau dalam suatu periode tertentu.

Menurut Munawir (2010: 5), Laporan keuangan adalah suatu bentuk pelaporan yang terdiri dari neraca dan perhitungan laba rugi serta laporan perubahan ekuitas. Neraca menunjukkan atau menggambarkan jumlah aset, kewajiban, dan ekuitas dari suatu perusahaan pada tanggal tertentu.

Menurut Muhardi (2013: 1), Laporan keuangan dapat diibaratkan sebuah peta yang berguna bagi pihak-pihak yang sedang melakukan perjalanan. Dengan melihat pada peta yang ada, maka pihak yang sedang melakukan perjalanan tersebut dapat mencapai tujuan akhir dengan cara yang tepat dan tidak tersesat ditengah perjalanan. Pengguna dari laporan keuangan sendiri adalah manajemen, investor, kreditur, dan pemangku kepentingan lainnya yang berhubungan dengan perusahaan.

Menurut Standar Akuntansi Keuangan (2017: 2), Laporan keuangan adalah suatu penyajian terstruktur dari posisi keuangan dan kinerja keuangan suatu entitas. Sedangkan pengertian laporan keuangan menurut Harahap (2015: 105), Laporan keuangan 
menggambarkan kondisi keuangan dan hasil usaha suatu perusahaan pada saat tertentu atau jangka waktu tertentu.

2. Pengertian Analisis Laporan Keuangan

Menurut Harahap (2015: 190), Analisis laporan keuangan adalah menguraikan pospos laporan keuangan (financial statement) menjadi unit informasi yang lebih kecil dan melihat hubungannya yang bersifat signifikan atau yang mempunyai makna antara satu dengan yang lain baik antara data kuantitatif maupun data non kuantitatif dengan tujuan untuk mengetahui kondisi keuangan lebih dalam yang sangat penting dalam proses menghasilkan keputusan yang tepat.

Menurut Prastowo (2015: 50), Analisis laporan keuangan merupakan suatu proses yang penuh pertimbangan dalam rangka membantu evaluasi posisi keuangan dan hasil operasi perusahaan pada masa sekarang dan masa lalu, dengan tujuan utama untuk menentukan estimasi dan prediksi yang paling mungkin mengenai kondisi keuangan dan kinerja perusahaan pada masa mendatang.

Menurut Herry (2015: 132), Analisis laporan keuangan merupakan suatu proses untuk membedah laporan keuangan kedalam unsur-unsurnya dan menelaah masing-masing dari unsur tersebut guna memperoleh pengertian dan pemahaman yang baik dan tepat atas laporan keuangan itu sendiri.

3. Pengertian Analisis Rasio Keuangan

Menurut Sartono (2010: 113), Analisis rasio keuangan adalah analisis keuangan yang mencakup analisis rasio keuangan, analisis kelemahan dan kekuatan dibidang keuangan akan sangat membantu dalam menilai prestasi manajemen masa lalu dan prospeknya dimasa yang akan dating. Rasio tersebut dapat memberikan indikasi apakah perusahaan memiliki kewajiban yang cukup untuk memenuhi kewajiban keuangannya, besarnya piutang yang cukup rasional, efisiensi manajemen persediaan, perencanaan pengeluaran investasi yang baik dan struktur modal yang sehat sehingga tujuan memaksimumkan kemakmuran pemegang saham dapat dicapai.

Menurut Kasmir (2016: 104), Analisis rasio keuangan adalah kegiatan membandingkan angka-angka yang ada dalam laporan keuangan. Perbandingan dapat dilakukan antara satu komponen dengan komponen dalam satu laporan keuangan atau antara komponen yang ada di antara laporan keuangan.

Menurut Munawir (2010: 37), Analisis rasio adalah suatu metode analisis untuk mengetahui hubungan dari pos-pos tertentu dalam neraca atau laporan laba rugi secara individua atau kombinasi dari kedua laporan tersebut.

4. Tujuan Analisis Rasio Keuangan

Tujuan analisis rasio keuangan menurut Munawir (2010: 64) adalah sebagai berikut :

a. Untuk keperluan pengukuran kerja keuangan secara menyeluruh.

b. Untuk keperluan pengukuran profitabilitas atau rentabilitas, kemampuan perusahaan untuk memperoleh keuntungan dari operasinya.

c. Untuk keperluan pengujian investasi.

d. Untuk keperluan pengujian kondisi keuangan antara lain tentang tingkat likuiditas dan solvabilitas. 
Menurut Hery (2015: 164) menyatakan bahwa manfaat rasio keuangan adalah sebagai berikut :

a. Untuk membantu menganalisis, mengendalikan, dan meningkatkan kinerja operasi serta keuangan perusahaan.

b. Untuk mengidentifikasi kemampuan debitur dalam membayar utang-utangnya.

5. Jenis-jenis Rasio Keuangan

Menurut Munawir (2010: 238) ada empat kelompok rasio keuangan yaitu :

a. Rasio likuiditas adalah rasio untuk mengetahui kemampuan perusahaan membiayai operasi dan memenuhi kewajiban keuangan saat ditagih.

b. Rasio aktivitas adalah rasio untuk mengetahui kemampuan perusahaan dalam melakukan aktivitas perusahaan sehari-hari.

c. Rasio profitabilitas adalah rasio untuk mengetahui kemampuan perusahaan untuk memeperoleh laba dari berbagai kebijakan dan keputusan yang diambil.

d. Rasio solvabilitas adalah rasio untuk mengukur seberapa jauh aktiva perusahaan dibiayai oleh utang.

Analisis rasio keuangan atas laporan keuangan akan menggambarkan suatu pertimbangan terhadap baik atau buruknya keadaan keuangan perusahaan dan bertujuan untuk menentukan seberapa efektif dan efisien manajemen dalam mengelola keuangan perusahaan. Berikut merupakan rasio keuangan yang berkaitan dengan masalah yang akan dibahas, yaitu rasio likuiditas, solvabilitas dan profitabilitas.

\section{Metodologi Penelitian}

\section{Teknik Pengumpulan Data}

Sumber data yang digunakan dalam penelitian ini adalah data sekunder yang merupakan sumber data tidak langsung. Data sekunder dalam penelitian ini adalah laporan keuangan yang diperoleh dan dipublikasikan oleh Bursa Efek Indonesia. Jenis data yang diperlukan dalam penelitian ini adalah data yang bersifat kuantitatif yang berbentuk angka dan data, sebagai data kuantitatif dalam penelitian ini adalah laporan keuangan periode 2014 sampai dengan 2019.

\section{Teknik Analisa Data}

1. Rasio likuiditas

Menurut Weston (Kasmir; 2008: 128) Rasio likuiditas adalah rasio yang menggambarkan kemampuan perusahaan untuk memenuhi kewajiban jangka pendeknya pada saat jatuh tempo. Rasio ini diwakili dengan menggunakan Current Ratio dan Quick Ratio.

a. Current Ratio

Current Ratio atau rasio lancar merupakan rasio untuk mengukur kemampuan perusahaan dalam membayar kewajiban jangka pendek atau utang yang segera jatuh tempo pada saat ditagih secara keseluruhan. Rumus untuk mencari current ratio dapat digunakan sebagai berikut :

Current Ratio $=\frac{\text { Aset Lancar }}{\text { Utang Lancar }}$


b. Quick Ratio

Quick ratio atau rasio cepat atau rasio sangat lancar merupakan rasio yang menunjukkan kemampuan perusahaan dalam memenuhi atau membayar kewajiban atau utang lancar (utang jangka pendek) dengan aktiva lancar tanpa memperhitungkan nilai persediaan (inventory). Rumus untuk mencari Quick ratio dapat digunakan sebagai berikut :

Quick Ratio

$$
=\frac{\text { Aset Lancar }- \text { Persediaan }}{\text { Utang Lancar }}
$$

2. Rasio solvabilitas

Rasio solvabilitas atau leverage ratio merupakan rasio yang digunakan untuk mengukur sejauh mana aktiva perusahaan dibiayai dengan utang. Artinya berapa besar beban utang yang ditanggung perusahaan dibandingkan dengan aktivanya. Rasio ini diwakili dengan menggunakan Debt to asset ratio (Debt ratio) dan Debt to equity ratio.

a. Debt to asset ratio (Debt ratio)

Debt ratio merupakan rasio utang yang digunakan untuk mengukur perbandingan antara total utang dengan total aktiva. Dengan kata lain, seberapa besar aktiva perusahaan dibiayai oleh utang atau seberapa besar utang perusahaan berpengaruh terhadap pengelolaan aktiva. Rumusan untuk mencari debt ratio dapat digunakan sebagai berikut :

Debt ratio

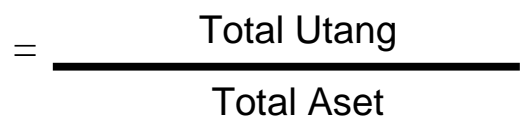

b. Debt to equity ratio

Debt to equity ratio merupakan rasio yang digunakan untuk menilai utang dengan ekuitas. Rasio ini dicari dengan cara membandingkan antara seluruh utang, termasuk utang lancar dengan seluruh ekuitas. Rumus untuk mencari debt to equity ratio dapat digunakan perbandingan antara total utang dengan total ekuitas sebagai berikut :

\section{Debt to Equity Ratio $\quad=\frac{\text { Total Utang }}{\text { Total Ekuitas }}$}

c. Equity multiplier

Equity multiplier yaitu rasio yang menunjukkan kemampuan perusahaan dalam mendayagunakan ekuitas pemegang saham. Rumusan untuk mencari equity multiplier dapat digunakan sebagai berikut :

Equity multiplier

d. Capital structure

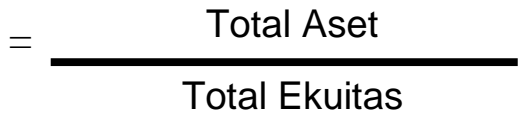


Capital structure merupakan rasio antara utang jangka panjang dengan modal sendiri. Tujuannya adalah untuk mengukur berapa bagian dari setiap rupiah modal sendiri yang dijadikan jaminan utang jangka panjang dengan cara membandingkan antara utang jangka Panjang dengan modal sendiri yang disediakan oleh perusahaan. Rumusan untuk mencari Capital structure dapat digunakan sebagai berikut :

Capital structure $\quad=\frac{\text { Utang jangka panjang }}{\text { Total Ekuitas }}$

3. Rasio aktivitas

Menurut Harahap (2009: 308) rasio aktivitas yaitu rasio yang mengukur efektivitas perusahaan dalam menjalankan operasionalnya yang dimiliki. Rasio ini diwakili dengan menggunakan Receivable turn over, Day's sales in receivable, Inventory turn over, Day's sales turn over, dan Total asset turn over.

a. Receivable turn over

Receivable turn over merupakan rasio yang digunakan untuk mengukur berapa lama penagihan piutang selama satu periode atau berapa kali dana yang ditanam dalam piutang ini berputar dalam satu periode. Rumusan untuk mencari Receivable turn over dapat digunakan sebagai berikut :

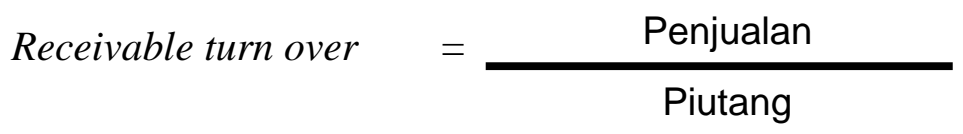

b. Day's sales in receivable

Day's sales in receivable merupakan hari rata-rata penagihan piutang. Rumusan untuk mencari Day's sales in receivable dapat digunakan sebagai berikut :

Day's sales in receivable $=\frac{365}{\text { Receivable turn over }}$

c. Inventory turn over

Inventory turn over merupakan rasio yang digunakan untuk mengukur berapa kali dana yang ditanam dalam persediaan ini berputar satu periode. Rumusan untuk mencari Inventory turn over dapat digunakan sebagai berikut :

Inventory turn over

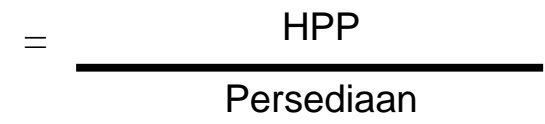

d. Day's sales turn over

Persediaan

Day's sales turn over merupakan rasio yang digunakan untuk mengukur berapa hari rata-rata persediaan tersimpan dalam gudang. Rumusan untuk mencari Day's sales turn over dapat digunakan sebagai berikut :

Day's sales turn over $\quad=\frac{365}{}$

Inventory turn over 
e. Total asset turn over

Total asset turn over merupakan rasio yang digunakan untuk mengukur perputaran semua aktiva yang dimiliki perusahaan dan mengukur berapa jumlah penjualan yang diperoleh dari tiap rupiah aktiva. Rumusan untuk mencari Total asset turn over dapat digunakan sebagai berikut :

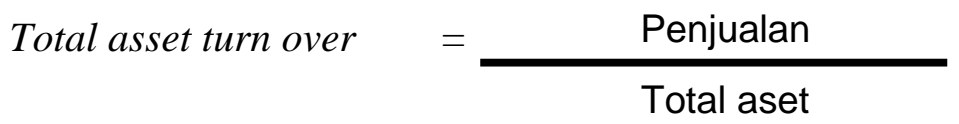

4. Rasio profitabilitas

Menurut Kasmir (2008: 196) rasio profitabilitas yaitu rasio yang menunjukkan kemampuan perusahaan untuk memperoleh keuntungan. Rasio ini juga memberikan ukuran tingkat efektivitas manajemen suatu perusahaan. Hal ini ditunjukkan oleh laba yang dihasilkan dari penjualan dan pendapatan investasi. Rasio ini diwakili dengan menggunakan Net profit margin, return on asset (ROA) dan return on equity (ROE).

a. Net profit margin

Net profit margin atau margin laba bersih merupakan ukuran keuntungan dengan membandingkan antara laba setelah bunga dan pajak dibandingkan dengan penjualan. Rasio ini menunjukkan pendapatan bersih perusahaan atas penjualan. Untuk margin laba bersih dengan rumus :
Net Profit Margin

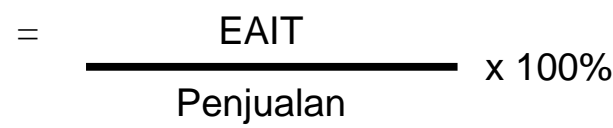

b. Return on asset (ROA) atau return on investment (ROI)

Hasil pengembalian investasi atau lebih dikenal dengan nama return on investment (ROI) atau return on asset (ROA) merupakan rasio yang menunjukkan hasil (return) atas jumlah aktiva yang digunakan dalam perusahaan. Rumus untuk mencari return on asset dapat digunakan sebagai berikut :

Return On Asset

$$
=\frac{\text { EAIT }}{\text { Total Aset }} \times 100 \%
$$

c. Return on equity (ROE)

Hasil pengembalian ekuitas atau return on equity atau rentabilitas modal sendiri merupakan rasio untuk mengukur laba bersih sesudah pajak dengan modal sendiri. Rasio ini menunjukkan efisiensi penggunaan modal sendiri. Semakin tinggi rasio ini, semakin baik. Artinya posisi pemilik perusahaan semakin kuat, demikian pula sebaliknya. Rumus untuk mencari return on equity dapat digunakan sebagai berikut :

Return On Equity

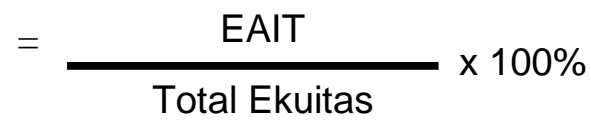




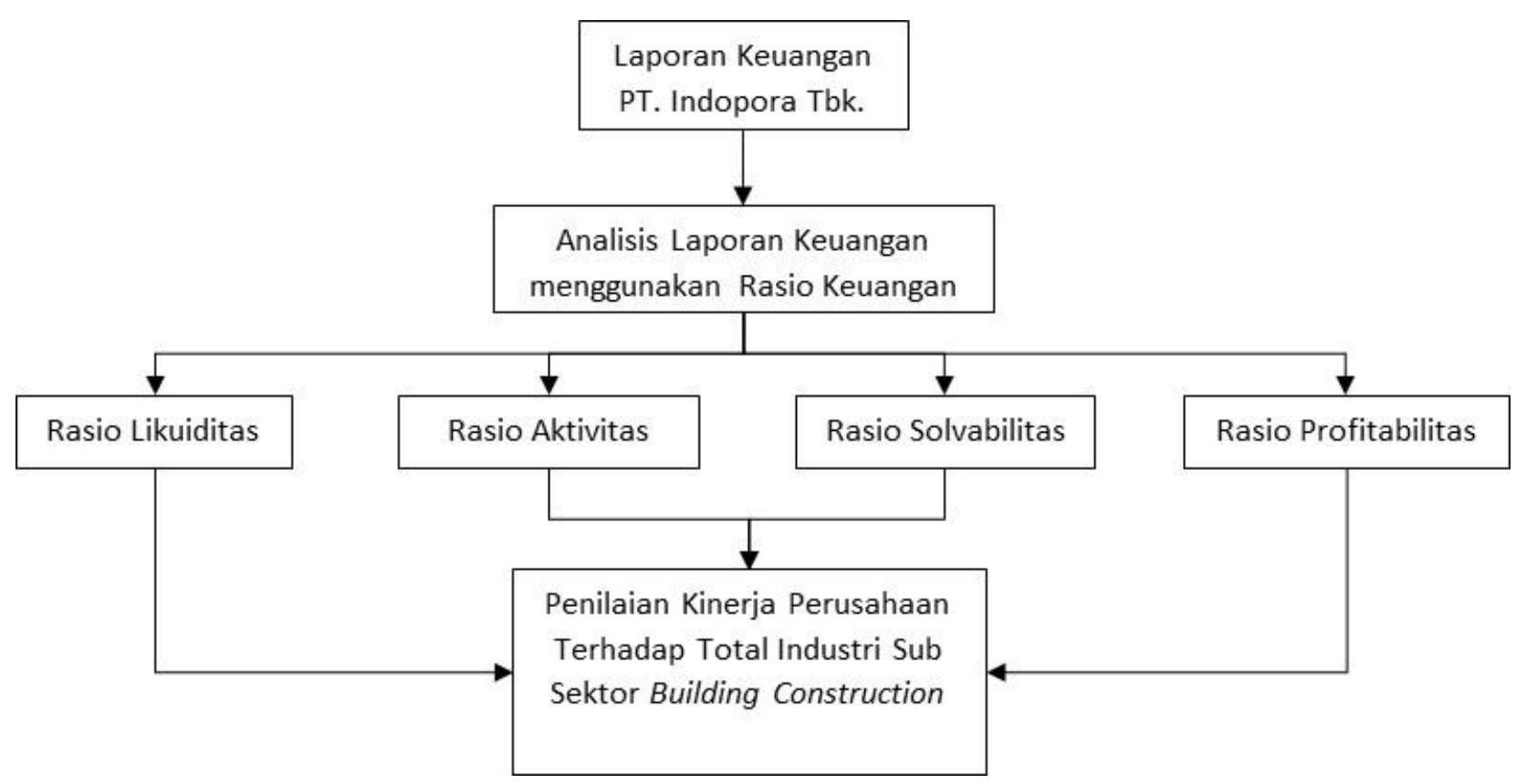

Kerangka konseptual

Gambar 1. Kerangka konseptual penilaian kinerja perusahaan 


\section{Hasil Analisis dan Pembahasan}

Berikut hasil perhitungan analisis rasio keuangan PT. Indonesia Pondasi Raya (Indopora) Tbk dan industri sub sektor building construction dari tahun 2014 sampai dengan tahun 2019 :

Tabel 1. Tabel Perhitungan Analisis Rasio

\begin{tabular}{|c|c|c|c|c|c|c|c|c|c|c|c|c|c|}
\hline \multirow{2}{*}{ Jenis Rasio } & \multirow{2}{*}{ Rumus } & \multicolumn{2}{|c|}{2014} & \multicolumn{2}{|c|}{2015} & \multicolumn{2}{|c|}{2016} & \multicolumn{2}{|r|}{2017} & \multicolumn{2}{|c|}{2018} & \multicolumn{2}{|c|}{2019} \\
\hline & & IDPR & \begin{tabular}{|l|} 
INDUSTRI \\
\end{tabular} & IDPR & INDUSTRI & IDPR & INDUSTRI & IDPR & INDUSTRI & IDPR & INDUSTRI & IDPR & INDUSTRI \\
\hline \multicolumn{14}{|c|}{ RASIO LIKUIDITAS } \\
\hline Current Ratio & Aktiva Lancar & \multirow{2}{*}{1,53} & \multirow{2}{*}{1,33} & \multirow{2}{*}{3,14} & \multirow{2}{*}{1,39} & \multirow{2}{*}{2,62} & \multirow{2}{*}{1,41} & \multirow{2}{*}{2,70} & \multirow{2}{*}{1,26} & \multirow{2}{*}{2,49} & \multirow{2}{*}{1,34} & \multirow{2}{*}{2,18} & \multirow{2}{*}{1,27} \\
\hline (satuan:kali) & Utang Lancar & & & & & & & & & & & & \\
\hline Quick Ratio & Aktiva Lancar - Persediaan & \multirow[b]{2}{*}{1,28} & & & & & & & & & & & \\
\hline (satuan:kali) & $\begin{array}{l}\text { Utang Lancar } \\
\end{array}$ & & 1,21 & 2,90 & 1,28 & 2,35 & 1,28 & 2,33 & 1,15 & 1,74 & 1,19 & 1,41 & 1,11 \\
\hline & & & & RASIO & SOLVABIL & TAS & & & & & & & \\
\hline Total Debt Ratio & Total Aktiva - Total Ekuitas & & & & & & & & & & & & \\
\hline (satuan:kali) & Total Aktiva & 0,49 & 0,93 & 0,28 & 0,95 & 0,28 & 0,94 & 0,34 & 0,94 & 0,36 & 0,93 & 0,39 & 0,93 \\
\hline & & & & & & & & & & & & & \\
\hline Debt Equity Ratio & Total Utang & 0.97 & 254 & 0.39 & & & & & & & & & \\
\hline (satuan:kali) & Total Ekuitas & 0,97 & 2,54 & 0,39 & 2,02 & 0,40 & 1,95 & 0,52 & 2,43 & $0,5 /$ & 2,63 & 0,65 & 2,68 \\
\hline & & & & & & & & & & & & & \\
\hline Equality Multiplier & Total Aktiva & 197 & 354 & 139 & 302 & 140 & 295 & 1.52 & 343 & 157 & 363 & 165 & 368 \\
\hline (satuan:kali) & Total Ekuitas & 1,97 & 3,54 & 1,39 & 3,02 & 1,40 & 2,95 & 1,52 & 3,43 & $1,5 /$ & 3,63 & 1,65 & 3,68 \\
\hline Capital Structure & Utang Jangka Paniang & & & & & & & & & & & & \\
\hline (satuan:kali) & Total Ekuitas & 0,19 & 0,51 & 0,10 & 0,50 & 0,07 & 0,47 & 0,22 & 0,60 & 0,27 & 0,84 & 0,26 & 0,94 \\
\hline & 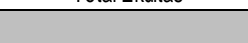 & & & RASIOT T & TURNOVER & ASET & & & & & & & \\
\hline Receivable Turnover & Peniualan & & & & & & & & & & & & \\
\hline (satuan:kali) & $\overline{P \text { Piutang }}$ & 3,45 & 2,17 & 2,16 & 1,92 & 1,49 & 1,52 & 1,72 & 1,40 & 1,86 & 1,32 & 1,88 & 1,22 \\
\hline & & & & & & & & & & & & & \\
\hline Day's Sale in Receivable & 365 hari & & & & & & & & & & & & \\
\hline \begin{tabular}{|l|} 
(satuan:hari) \\
\end{tabular} & Receivable Turnover & 105,84 & $16 /, 89$ & 168,18 & 190,41 & 245,65 & 240,30 & 212,03 & 259,97 & 196,00 & $2 / 6,24$ & 194,23 & 298,19 \\
\hline Inventory Turnover & HPP & & & & & & & & & & & & \\
\hline (satuan:kali) & Persediaan & 10,97 & 11,18 & 11,75 & 11,13 & 7,62 & 7,51 & 6,74 & 8,18 & 2,65 & 6,14 & 2,24 & 4,82 \\
\hline & & & & & & & & & & & & & \\
\hline Day's Sale Turnover & 365 hari & & & & & & & & & & & & \\
\hline (satuan:hari) & Inventory Turnover & 33,26 & 32,65 & 31,07 & 32,80 & 47,88 & 48,57 & 54,14 & 44,60 & 137,79 & 59,44 & 163,04 & 75,67 \\
\hline & & & & & & & & & & & & & \\
\hline Total Aset Turnover & Peniualan & 137 & 088 & 084 & 067 & 065 & 051 & 064 & 0.53 & 0.48 & 0.48 & 0.48 & 039 \\
\hline (satuan:kali) & Total Aktiva & 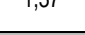 & 0,00 & & & $0,0 \mathrm{~J}$ & ( & 0,04 & , & & & & \\
\hline & & & & RASIO F & PROFITABII & LITAS & & & & & & & \\
\hline Profit Margin & Laba Bersih & $1486 \%$ & $569 \%$ & $1975 \%$ & $675 \%$ & $11.97 \%$ & $602 \%$ & $971 \%$ & $789 \%$ & $339 \%$ & $707 \%$ & $-37 \%$ & $435 \%$ \\
\hline (satuan:\%) & Penjualan & $14,80 \%$ & $5,09 \%$ & $19, / 5 \%$ & $0,15 \%$ & $11,9 / \%$ & b,u2\% & $y, / 1 \%$ & 1,89\% & 3,35\% & $1,0 / \%$ & $-0,3 / \%$ & $4,35 \%$ \\
\hline & & & & & & & & & & & & & \\
\hline Return On Asset & Laba Bersih & $2040 \%$ & $500 \%$ & $1649 \%$ & $453 \%$ & $778 \%$ & $310 \%$ & $619 \%$ & $418 \%$ & $162 \%$ & $342 \%$ & $-18 \%$ & $168 \%$ \\
\hline (satuan:\%) & Total Aktiva & $20,40 \%$ & , ,00\% & $16,49 \%$ & $4,53 \%$ & $1,18 \%$ & $3,10 \%$ & $6,19 \%$ & $4,18 \%$ & $1,62 \%$ & $3,42 \%$ & $-0,18 \%$ & $1,68 \%$ \\
\hline Return On Equity & Laba Bersih & & & & & & & & & & & & \\
\hline (satuan:\%) & Total Ekuitas & $40,11 \%$ & $17,72 \%$ & $22,96 \%$ & $13,66 \%$ & $10,88 \%$ & $9,12 \%$ & $9,43 \%$ & $14,32 \%$ & $2,55 \%$ & $12,40 \%$ & $-0,29 \%$ & $6,20 \%$ \\
\hline & & & & & & & & & & & & & \\
\hline
\end{tabular}


1. Analisis Rasio Likuiditas

Analisis ini dilakukan untuk mengetahui kemampuan PT. Indonesia Pondasi Raya Tbk. dan Total Industri Sub Sektor Building Construction dalam memenuhi kewajiban jangka pendek. Rasio likuiditas yang digunakan dalam penulisan ini adalah Current Ratio dan Quick Ratio.

a. Current Ratio

Berikut adalah grafik Current Ratio pada PT. Indonesia Pondasi Raya Tbk. dan Total Industri Sub Sektor Building Construction.

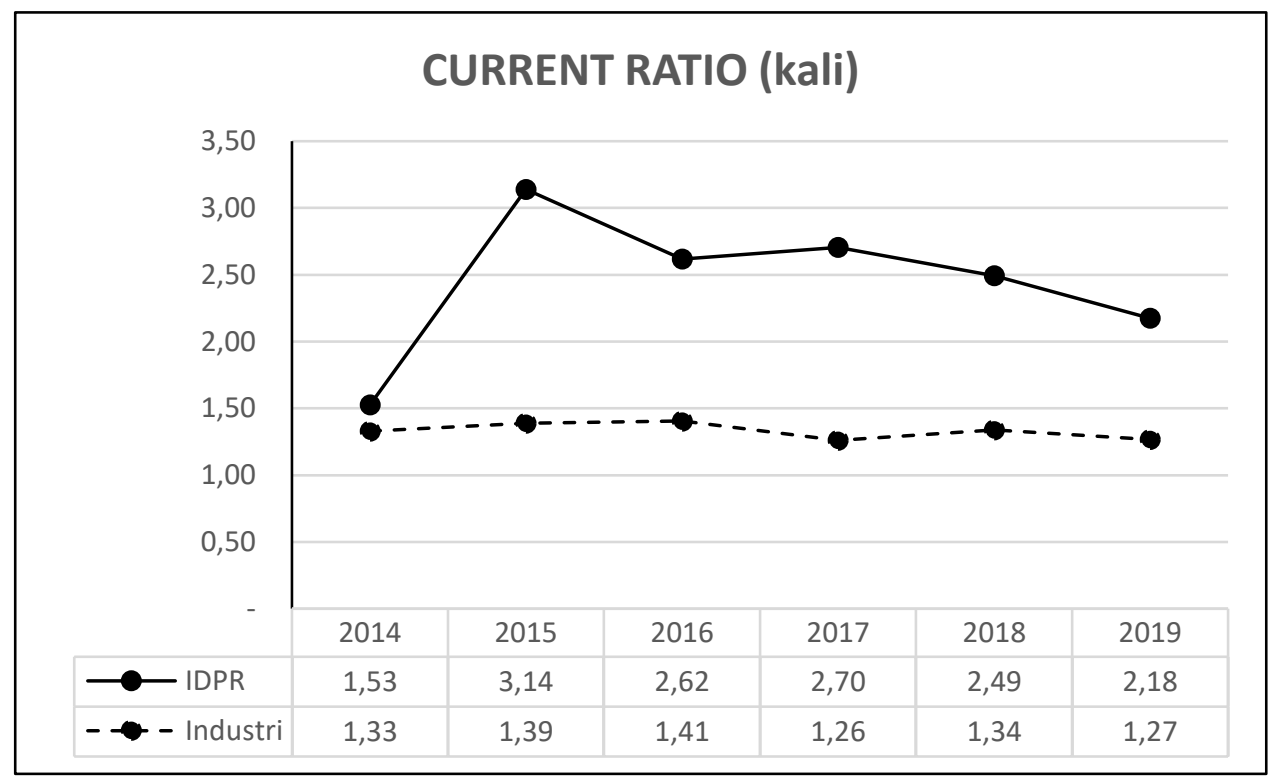

Grafik 1. Grafik Current Ratio PT. Indonesia Pondasi Raya Tbk dan Total Industri Sub Sektor Building Construction

Berdasarkan grafik diatas kita dapat melihat nilai Current Ratio PT. Indonesia Pondasi Raya Tbk. dan nilai Current Ratio Total Industri Sub Sektor Building Construction dari tahun 2014 sampai dengan 2019. Untuk hasil perbandingan selama lima tahun berturut-turut dapat dilihat bahwa nilai Current Ratio PT. Indonesia Pondasi Raya Tbk. berada posisi lebih tinggi dibandingkan dengan Total Industri Sub Sektor Building Construction.

Dalam Current Ratio yang memiliki nilai > 1 menunjukkan bahwa aktiva lancar $>$ utang lancar, yang berarti perusahaan dianggap mampu memenuhi segala kewajiban-kewajiban jangka pendeknya. Akan tetapi nilai Current Ratio yang terlalu tinggipun tidak cukup baik, karena Current Ratio yang terlalu tinggi menunjukkan bahwa perusahaan memiliki tingkat likuiditas yang tinggi pula. Semakin tinggi tingkat likuiditas berarti aktiva maupun dana yang likuid yang ada di perusahaan terlalu banyak jumlahnya dan perusahaan tidak banyak mengalokasikan aktiva atau dana tersebut secara optimal.

Jadi, apabila dilihat dari nilai Current Rationya dapat disimpulkan bahwa PT. Indonesia Pondasi Raya lebih baik dibandingkan dengan Total Industri Sub Sektor Building Construction. 
b. Quick Ratio

Berikut adalah grafik Quick Ratio pada PT. Indonesia Pondasi Raya Tbk. dan Total Industri Sub Sektor Building Construction.

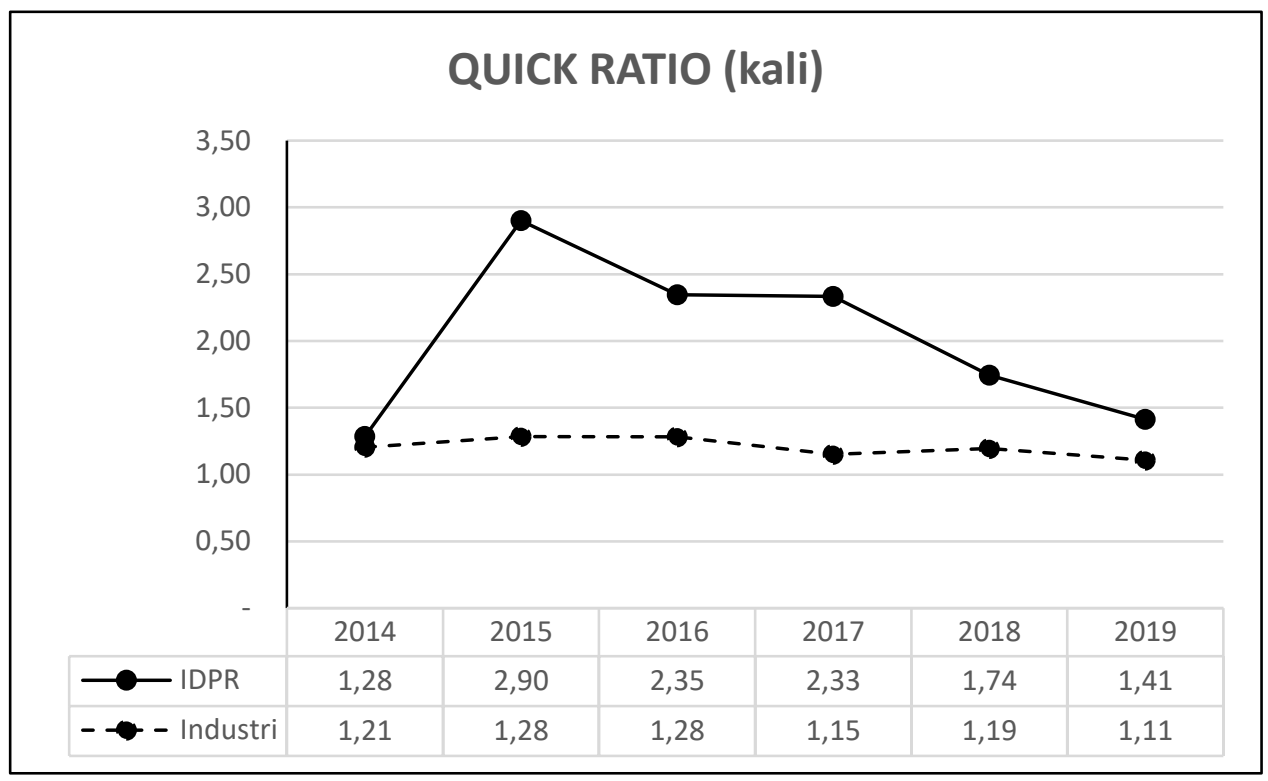

Grafik 2. Grafik Quick Ratio PT. Indonesia Pondasi Raya Tbk dan Total Industri Sub Sektor Building Construction

Berdasarkan grafik diatas kita dapat melihat nilai Quick Ratio PT. Indonesia Pondasi Raya Tbk. dan nilai Quick Ratio Total Industri Sub Sektor Building Construction dari tahun 2014 sampai dengan 2019. Untuk hasil perbandingan selama lima tahun berturut-turut dapat dilihat bahwa nilai Quick Ratio PT. Indonesia Pondasi Raya Tbk. berada posisi lebih tinggi dibandingkan dengan Total Industri Sub Sektor Building Construction.

Sama seperti Current Ratio, Quick Ratio juga menggambarkan tingkat likuiditas suatu perusahaan karena Quick Ratio merupakan hasil pembagian aktiva lancar setelah dikurangi persediaan dengan utang lancar. Oleh karena itu Quick Ratio yang memiliki nilai > 1 juga dianggap baik seperti pada Current Ratio, hal ini dikarenakan perusahaan tetap mampu memenuhi segala kewajiban-kewajiban jangka pendeknya dengan aktiva lancar yang dimiliki perusahaan walaupun telah dikurangi dengan persediaan, dan begitu pula sebaliknya.

Jadi, apabila dilihat dari nilai Quick Rationya dapat disimpulkan bahwa PT. Indonesia Pondasi Raya Tbk. lebih baik dibandingkan dengan Total Industri Sub Sektor Building Construction.

2. Analisis Rasio Solvabilitas

Analisis ini dilakukan untuk mengetahui kemampuan perusahaan terhadap seluruh kewajibannya. Analisis Solvabilitas yang dilakukan menggunakan Total Debt Ratio, Debt Equity Ratio, Equity Multiplier dan Capital Structure. 
a. Total Debt Ratio

Berikut adalah grafik Total Debt Ratio pada PT. Indonesia Pondasi Raya Tbk. dan Total Industri Sub Sektor Building Construction.

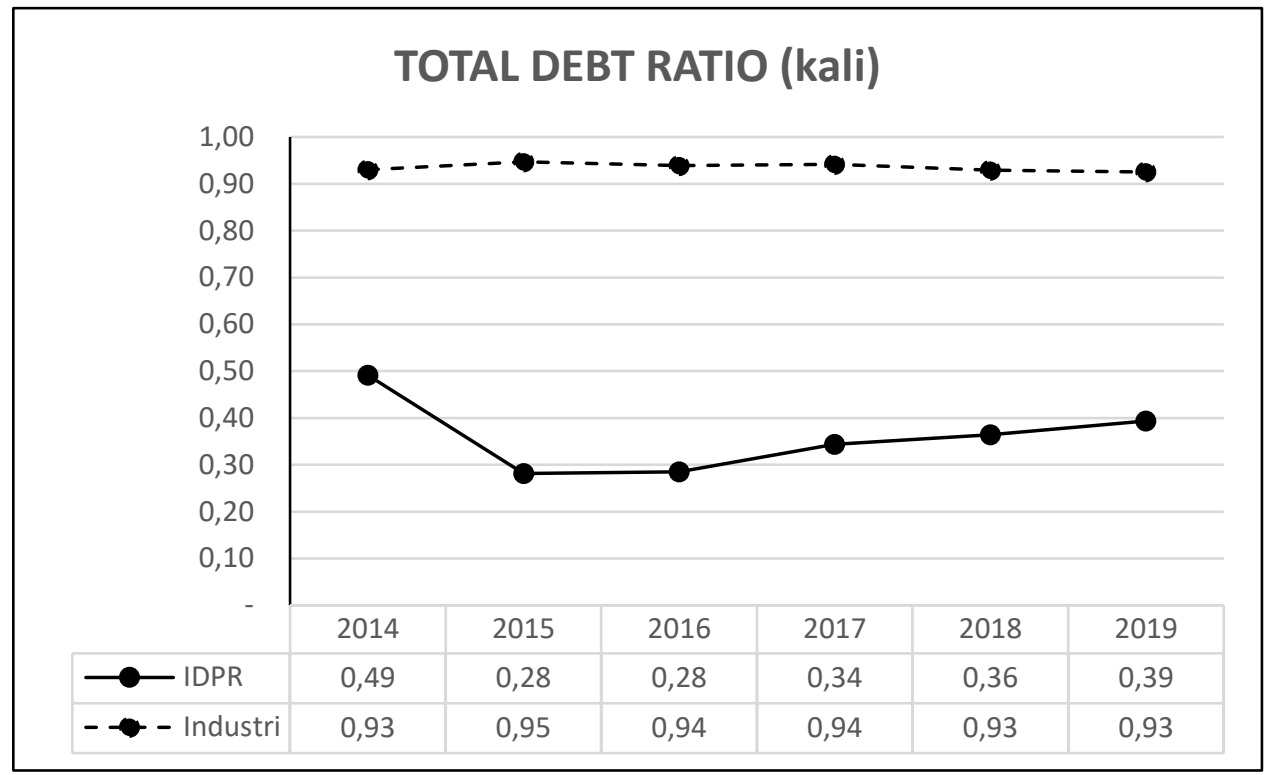

Grafik 3. Grafik Total Debt Ratio PT. Indonesia Pondasi Raya Tbk dan Total Industri Sub Sektor Building Construction

Berdasarkan grafik diatas kita dapat melihat nilai Total Debt Ratio PT. Indonesia Pondasi Raya Tbk. dan nilai Total Debt Ratio Total Industri Sub Sektor Building Construction dari tahun 2014 sampai dengan 2019. Untuk hasil perbandingan selama lima tahun berturut-turut dapat dilihat bahwa nilai Total Debt Ratio Total Industri Sub Sektor Building Construction berada posisi lebih tinggi dibandingkan dengan PT. Indonesia Pondasi Raya Tbk.

Total Debt Ratio dapat menunjukkan seberapa besar aktiva yang dimiliki oleh perusahaan dibiayai oleh hutang. Semakin besar nilai rasio ini artinya aktiva yang dimiliki oleh perusahaan dibiayai atau dibeli dengan menggunakan hutang. Sehingga semakin besar nilai dari rasio ini maka semakin besar pula risiko bagi para kreditur atau pihak yang memberikan pinjaman kepada perusahaan.

Jadi, apabila dilihat dari nilai Total Debt Rationya dapat disimpulkan bahwa PT. Indonesia Pondasi Raya Tbk. lebih baik dibandingkan dengan Total Industri Sub Sektor Building Construction. 
b. Debt Equity Ratio

Berikut adalah grafik Debt Equity Ratio pada PT. Indonesia Pondasi Raya Tbk. dan Total Industri Sub Sektor Building Construction.

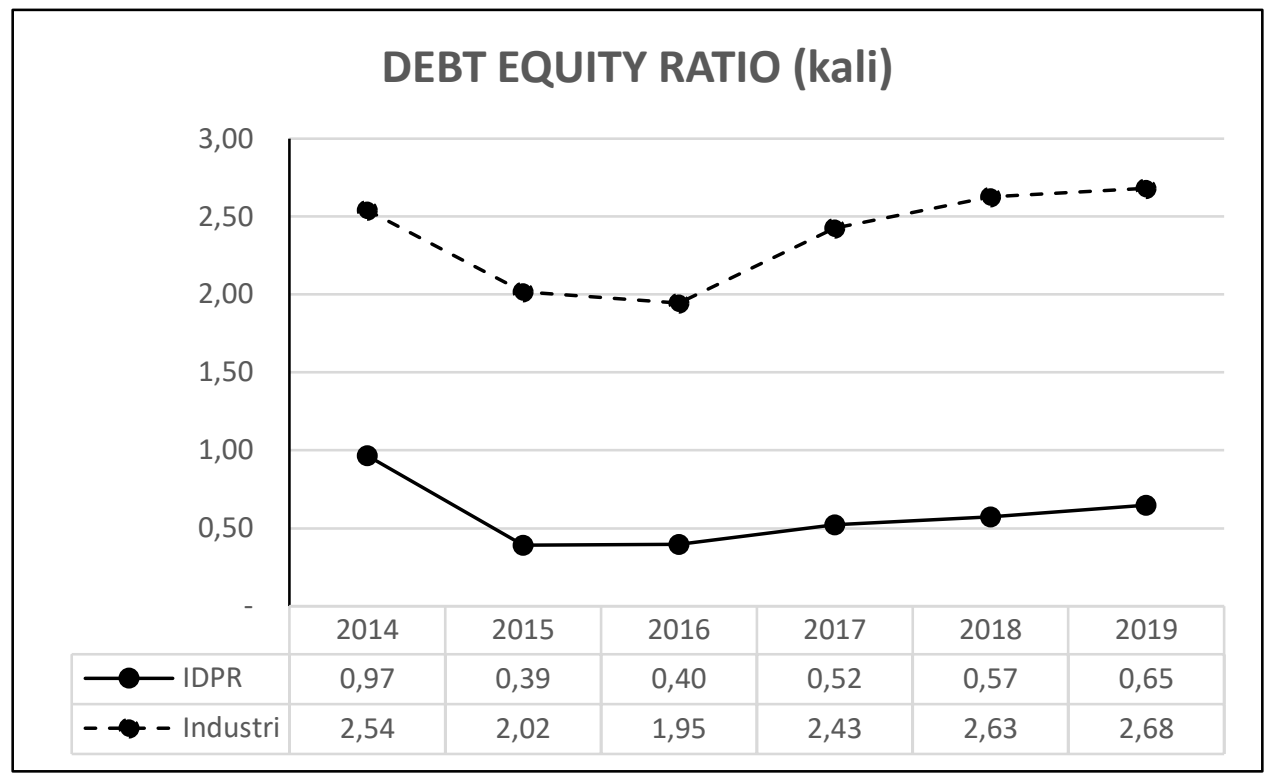

Grafik 4. Grafik Debt Equity Ratio PT. Indonesia Pondasi Raya Tbk dan Total Industri Sub Sektor Building Construction

Berdasarkan grafik diatas kita dapat melihat nilai Debt Equtiy Ratio PT. Indonesia Pondasi Raya Tbk. dan nilai Debt Equtiy Ratio Total Industri Sub Sektor Building Construction dari tahun 2014 sampai dengan 2019. Untuk hasil perbandingan selama lima tahun berturut-turut dapat dilihat bahwa nilai Debt Equtiy Ratio Total Industri Sub Sektor Building Construction berada posisi lebih tinggi dibandingkan dengan PT. Indonesia Pondasi Raya Tbk.

Debt Equity Ratio dapat menunjukkan seberapa besar ekuitas atau modal yang dimiliki oleh perusahaan dibiayai oleh hutang. Semakin besar nilai dari rasio ini artinya modal yang dimiliki oleh perusahaan berasal dari pinjaman atau hutang. Sehingga semakin besar nilai dari rasio ini maka semakin besar pula risiko bagi para kreditur atau pihak yang memberikan pinjaman kepada perusahaan.

Jadi, apabila dilihat dari nilai Debt Equity Rationya dapat disimpulkan bahwa PT. Indonesia Pondasi Raya Tbk. lebih baik dibandingkan dengan Total Industri Sub Sektor Building Construction. 


\section{c. Equity Multiplier}

Berikut adalah grafik Equity Multiplier pada PT. Indonesia Pondasi Raya Tbk. dan Total Industri Sub Sektor Building Construction.

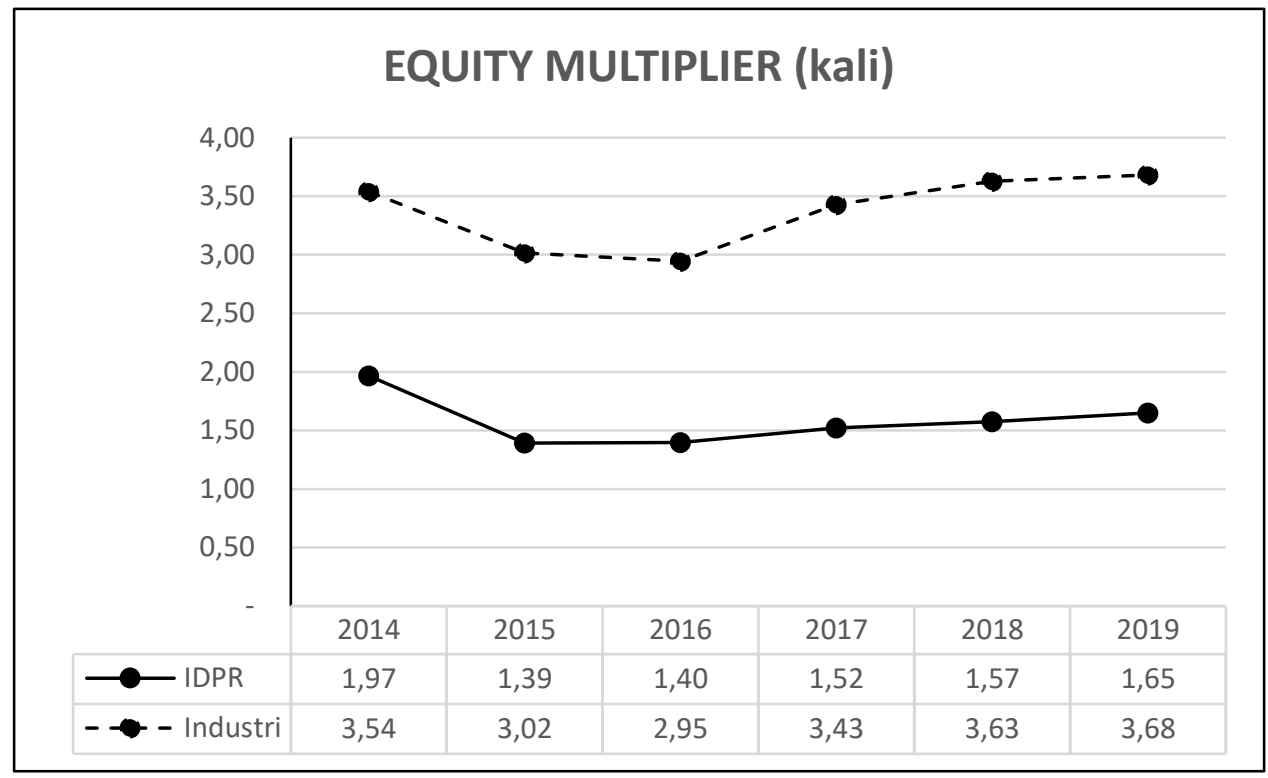

Grafik 5. Grafik Equity Multiplier PT. Indonesia Pondasi Raya Tbk dan Total Industri Sub Sektor Building Construction

Berdasarkan grafik diatas kita dapat melihat nilai Equity Multiplier PT. Indonesia Pondasi Raya Tbk. dan nilai Equity Multiplier Total Industri Sub Sektor Building Construction dari tahun 2014 sampai dengan 2019. Untuk hasil perbandingan selama lima tahun berturut-turut dapat dilihat bahwa nilai Equity Multiplier Total Industri Sub Sektor Building Construction berada posisi lebih tinggi dibandingkan dengan PT. Indonesia Pondasi Raya Tbk.

Equity Multiplier adalah rasio yang dapat menunjukkan kemampuan perusahaan dalam memanfaatkan ekuitas atau modal yang dimilikinya secara optimal. Rasio ini juga dapat menunjukkan seberapa besar aktiva yang dimiliki perusahaan dibiayai oleh ekuitas atau modalnya. Semakin rasio ini semakin baik bagi perusahaan, karena semakin kecil rasio ini maka semakin besar jumlah modal yang dimiliki perusahaan untuk membiayai aktiva bagi perusahaan.

Jadi, apabila dilihat dari nilai Equity Multipliernya dapat disimpulkan bahwa PT. Indonesia Pondasi Raya Tbk. lebih baik dibandingkan dengan Total Industri Sub Sektor Building Construction. 


\section{d. Capital Structure}

Berikut adalah grafik Capital Structure pada PT. Indonesia Pondasi Raya Tbk. dan Total Industri Sub Sektor Building Construction.

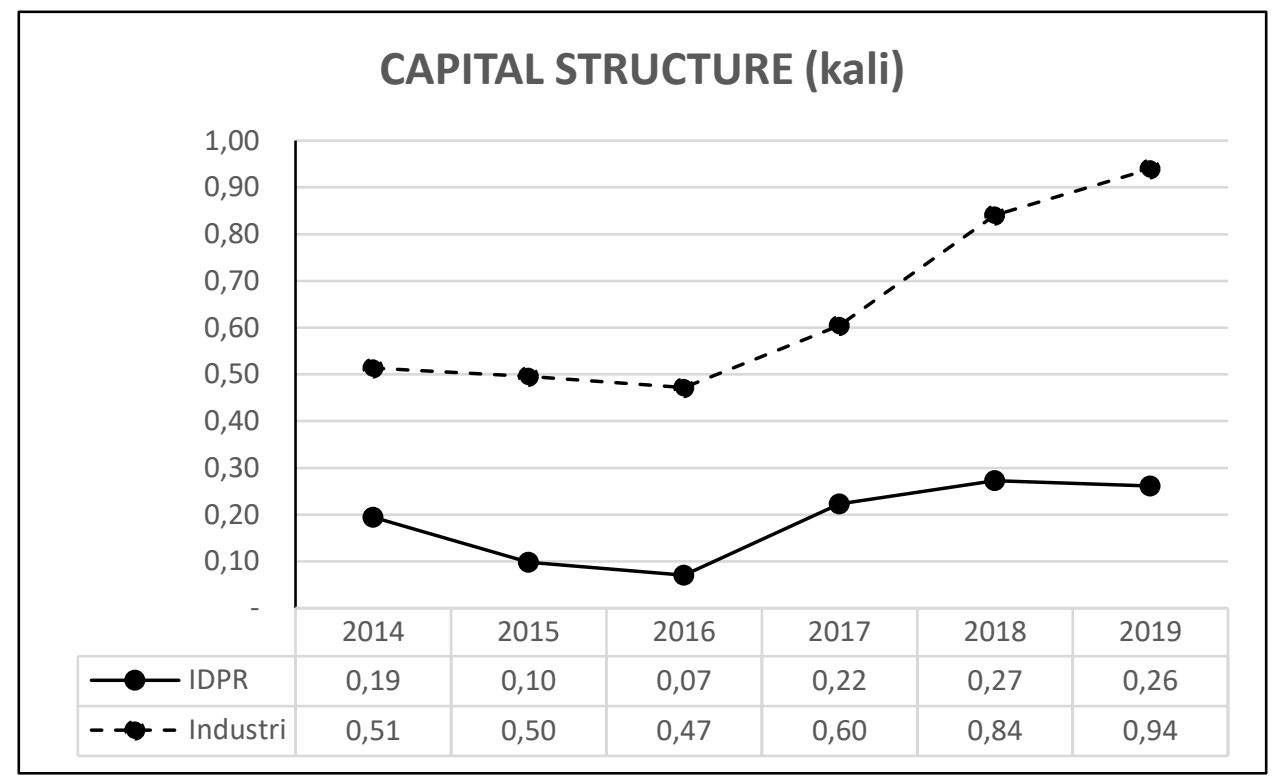

Grafik 6. Grafik Capital Structure PT. Indonesia Pondasi Raya Tbk dan Total Industri Sub Sektor Building Construction

Berdasarkan grafik diatas kita dapat melihat nilai Capital Structure PT. Indonesia Pondasi Raya Tbk. dan nilai Capital Structure Total Industri Sub Sektor Building Construction dari tahun 2014 sampai dengan 2019. Untuk hasil perbandingan selama lima tahun berturut-turut dapat dilihat bahwa nilai Capital Structure Total Industri Sub Sektor Building Construction berada posisi lebih tinggi dibandingkan dengan PT. Indonesia Pondasi Raya Tbk.

Capital Structure dapat menunjukkan seberapa besar ekuitas atau modal yang dimiliki oleh perusahaan dibiayai atau berasal dari hutang jangka panjang. Semakin besar nilai dari rasio ini artinya ekuitas atau modal yang dimiliki oleh perusahaan sebagian besar berasal dari pinjaman atau hutang jangka panjang. Apabila perusahaan terlalu banyak memiliki hutang jangka panjang maka akan semakin besar pula beban bunga yang ditanggung oleh perusahaan, karena hutang jangka panjang memiliki persentase bunga yang cukup tinggi. Oleh karena itu semakin kecil nilai dari rasio ini maka akan semakin baik bagi suatu perusahaan.

Jadi, apabila dilihat dari nilai Capital Structure nya dapat disimpulkan bahwa PT. Indonesia Pondasi Raya Tbk. lebih baik dibandingkan dengan Total Industri Sub Sektor Building Construction. 
3. Rasio Aktivitas

Analisis digunakan untuk mengukur penggunaan aset dalam meningkatkan penjualan, termasuk dalam analisis ini adalah Receivable turn over, Day's sales in receivable, Inventory turn over, Day's sales turn over, dan Total asset turn over.

a. Receivable Turn Over

Berikut adalah grafik Receivable turn over pada PT. Indonesia Pondasi Raya Tbk. dan Total Industri Sub Sektor Building Construction.

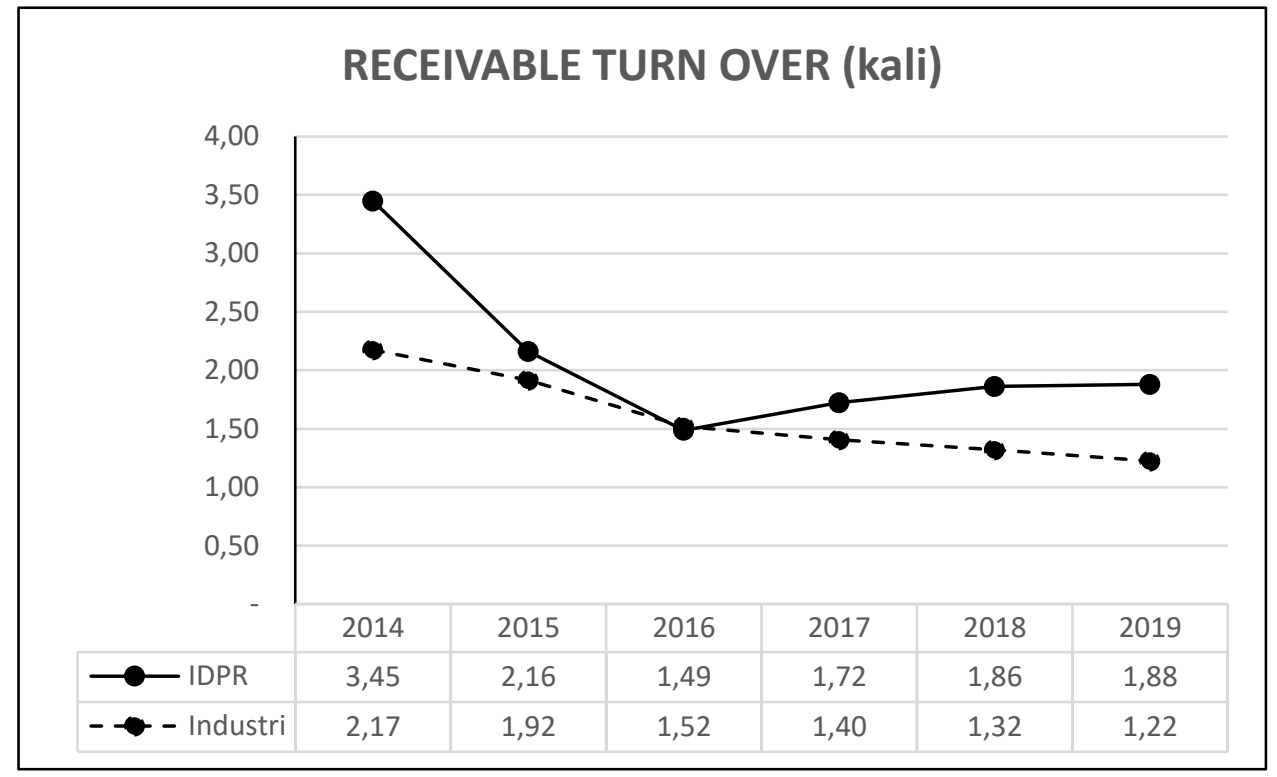

Grafik 7. Grafik Receivable turn over PT. Indonesia Pondasi Raya Tbk dan Total Industri Sub Sektor Building Construction

Berdasarkan grafik diatas kita dapat melihat nilai Receivable turn over PT. Indonesia Pondasi Raya Tbk. dan nilai Receivable turn over Total Industri Sub Sektor Building Construction dari tahun 2014 sampai dengan 2019. Untuk hasil perbandingan selama lima tahun berturut-turut dapat dilihat bahwa nilai Receivable turn over PT. Indonesia Pondasi Raya Tbk. hampir semua berada posisi lebih tinggi dibandingkan dengan Total Industri Sub Sektor Building Construction, hanya pada tahun 2016 nilai Receivable turn over PT. Indonesia Pondasi Raya Tbk. lebih rendah dari Total Industri Sub Sektor Building Construction. Hasil rata-rata nilai Receivable turn over PT. Indonesia Pondasi Raya Tbk selama lima tahun adalah 2,51 kali, sedangkan hasil rata-rata nilai Receivable turn over Total Industri Sub Sektor Building Construction adalah 1,9 kali sehingga dapat disimpulkan bahwa nilai Receivable turn over PT. Indonesia Pondasi Raya Tbk. berada posisi lebih tinggi dibandingkan dengan Total Industri Sub Sektor Building Construction.

Receivable turn over dapat menunjukkan berapa kali piutang dapat berputar dalam setahun. Semakin tinggi nilai Receivable turn over atau perputaran piutang pada perusahaan, artinya piutang yang dapat ditagih oleh perusahaan juga semakin banyak sehingga akan memperkecil kemungkinan adanya piutang yang tidak tertagih serta akan memperlancar arus kas. Oleh karena itu semakin tinggi nilai Receivable turn over atau perputaran piutang pada perusahaan maka akan semakin baik. 
Jadi, apabila dilihat dari nilai Receivable turn overnya dapat disimpulkan bahwa PT. Indonesia Pondasi Raya Tbk. lebih baik dibandingkan dengan Total Industri Sub Sektor Building Construction.

b. Day's sales in receivable

Berikut adalah grafik Day's sales in receivable pada PT. Indonesia Pondasi Raya Tbk. dan Total Industri Sub Sektor Building Construction.

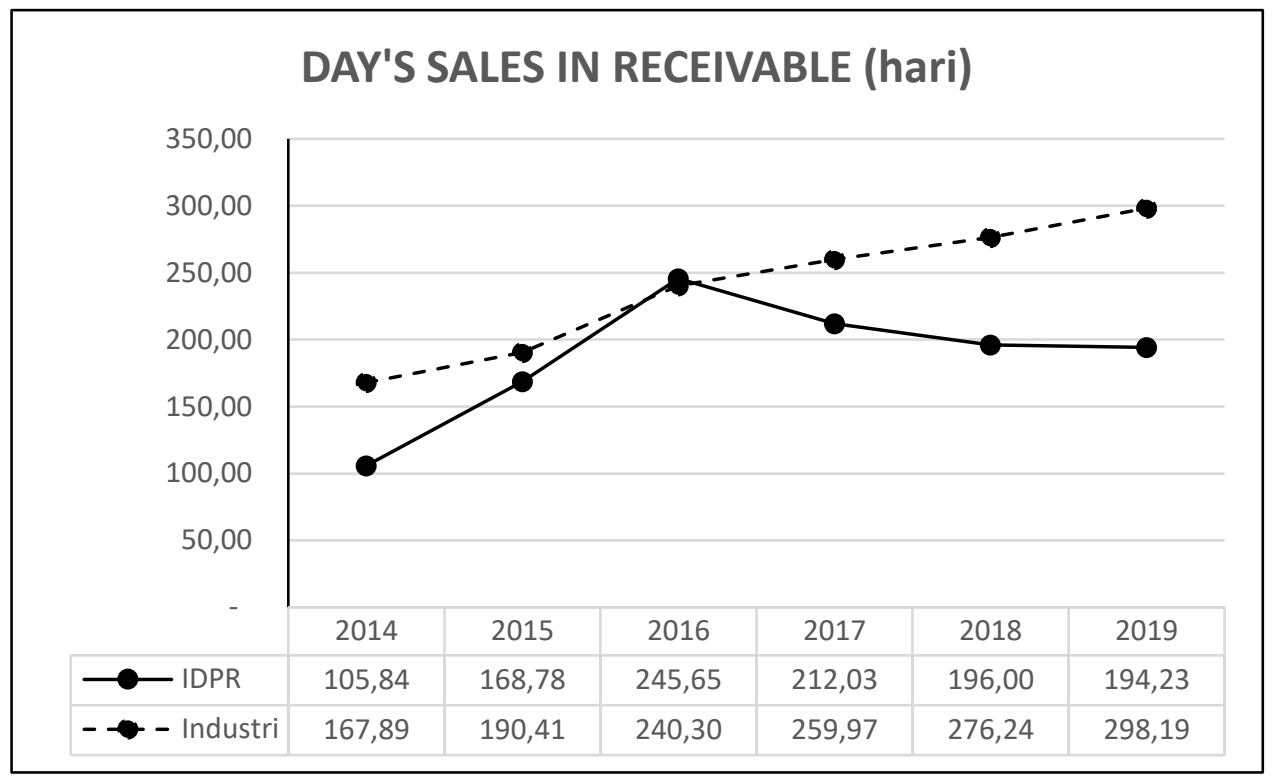

Grafik 8. Grafik Day's sales in receivable PT. Indonesia Pondasi Raya Tbk dan Total Industri Sub Sektor Building Construction

Berdasarkan grafik diatas kita dapat melihat nilai Receivable turn over PT. Indonesia Pondasi Raya Tbk. dan nilai Day's sales in receivable Total Industri Sub Sektor Building Construction dari tahun 2014 sampai dengan 2019. Hasil rata-rata nilai Day's sales in receivable PT. Indonesia Pondasi Raya Tbk selama lima tahun adalah 224,51 hari, sedangkan hasil rata-rata nilai Day's sales in receivable Total Industri Sub Sektor Building Construction adalah 286,6 hari sehingga dapat disimpulkan bahwa nilai Day's sales in receivable Total Industri Sub Sektor Building Construction berada posisi lebih tinggi dibandingkan dengan PT. Indonesia Pondasi Raya Tbk.

Day's sales in receivable dapat menunjukkan berapa lama rata-rata waktu yang dibutuhkan perusahaan untuk menagih setiap piutang yang ada, atau dapat juga dikatakan bahwa rasio ini dapat menunjukkan berapa lama rata-rata waktu yang dibutuhkan dalam pelunasan piutang perusahaan. Semakin kecil nilai Day's sales in receivable, artinya semakin cepat piutang dilunasi atau semakin cepat perusahaan mampu menagih piutang perusahaan sehingga akan memperkecil kemungkinan adanya piutang yang tidak tertagih serta akan memperlancar arus kas. Oleh karena itu semakin kecil Day's sales in receivable pada perusahaan maka akan semakin baik.

Jadi, apabila dilihat dari nilai Day's sales in receivablenya dapat disimpulkan bahwa PT. Indonesia Pondasi Raya Tbk. lebih baik dibandingkan dengan Total Industri Sub Sektor Building Construction. 
c. Inventory turn over

Berikut adalah grafik Inventory turn over pada PT. Indonesia Pondasi Raya Tbk. dan Total Industri Sub Sektor Building Construction.

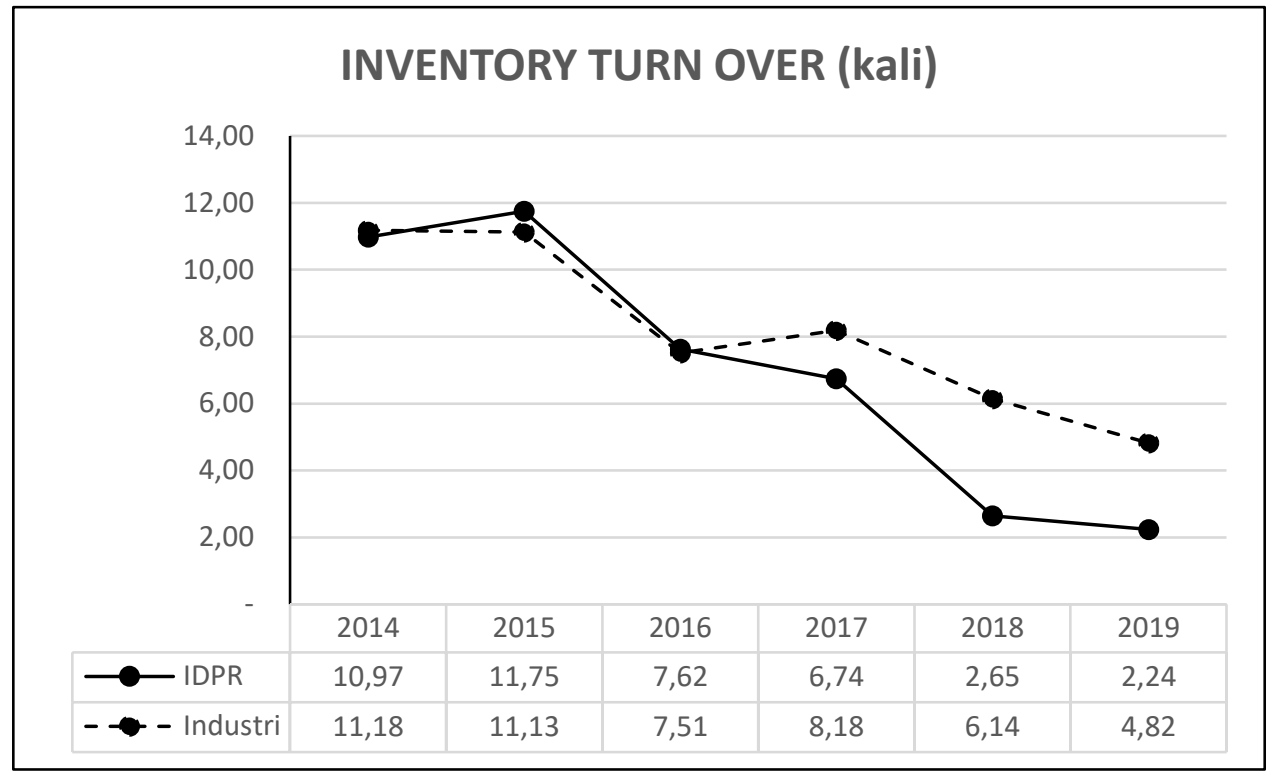

Grafik 9. Grafik Inventory turn over PT. Indonesia Pondasi Raya Tbk dan Total Industri Sub Sektor Building Construction

Berdasarkan grafik diatas kita dapat melihat nilai Inventory turn over PT. Indonesia Pondasi Raya Tbk. dan nilai Inventory turn over Total Industri Sub Sektor Building Construction dari tahun 2014 sampai dengan 2019. Hasil rata-rata nilai Inventory turn over PT. Indonesia Pondasi Raya Tbk selama lima tahun adalah 8,4 kali, sedangkan hasil ratarata nilai Inventory turn over Total Industri Sub Sektor Building Construction adalah 9,79 kali sehingga dapat disimpulkan bahwa nilai Inventory turn over Total Industri Sub Sektor Building Construction berada posisi lebih tinggi dibandingkan dengan PT. Indonesia Pondasi Raya Tbk.

Inventory turn over dapat menunjukkan berapa kali persediaan dapat berputar dalam satu tahun, atau dapat juga dikatakan bahwa rasio ini dapat menunjukkan tingkat efisiensi dari persediaan. Semakin tinggi nilai Inventory turn over artinya perusahaan dapat menjual persediaan secara maksimal sehingga tidak terjadi penumpukan persediaan di gudang, selain itu tingginya nilai Inventory turn over juga menunjukkan semakin tingginya perputaran persediaan sehingga dana yang tertanam pada persediaan dapat berputar kembali menjadi uang kas perusahaan. Oleh karena itu, semakin tinggi nilai Inventory turn over pada perusahaan maka akan semakin baik.

Jadi, apabila dilihat dari nilai Inventory turn overnya dapat disimpulkan bahwa PT. Indonesia Pondasi Raya Tbk. tidak lebih baik dibandingkan dengan Total Industri Sub Sektor Building Construction.

d. Day's sales turn over

Berikut adalah grafik Day's sales turn over pada PT. Indonesia Pondasi Raya Tbk. dan Total Industri Sub Sektor Building Construction. 


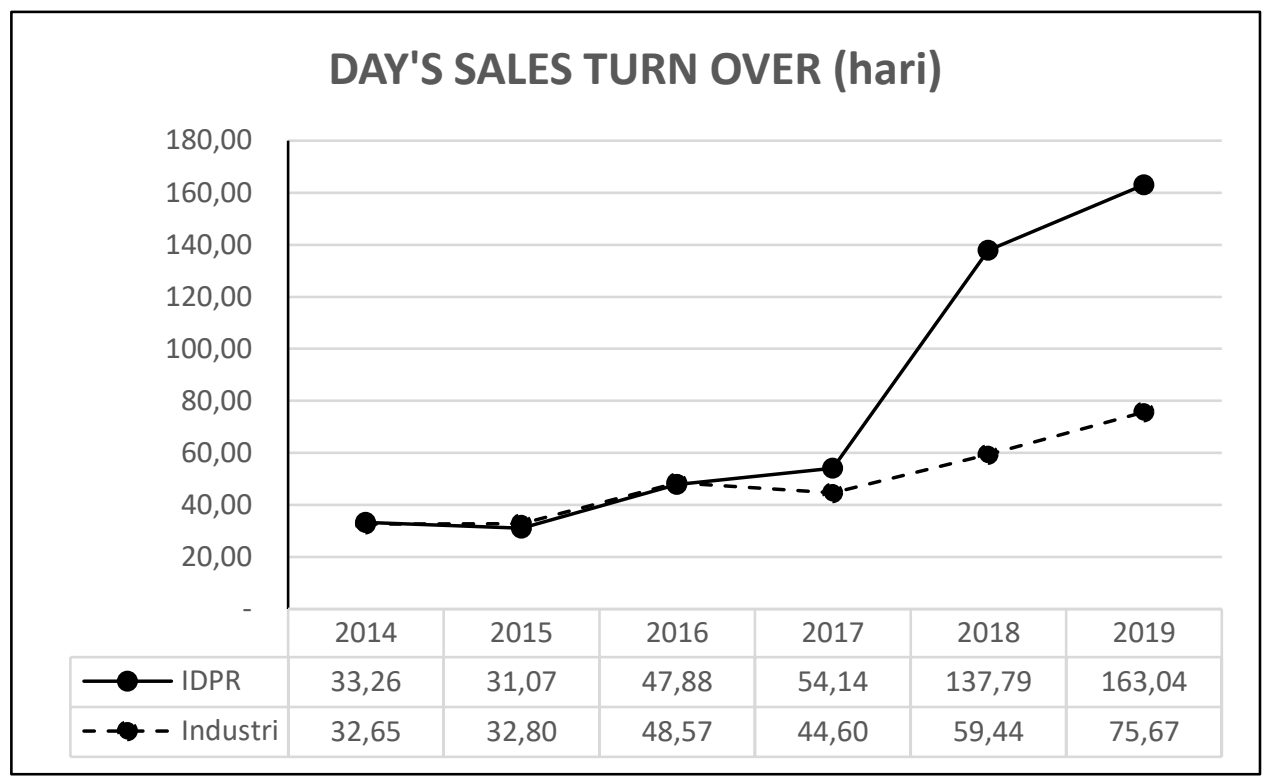

Grafik 10. Grafik Day's sales turn over PT. Indonesia Pondasi Raya Tbk dan Total Industri Sub Sektor Building Construction

Berdasarkan grafik diatas kita dapat melihat nilai Day's sales turn over PT. Indonesia Pondasi Raya Tbk. dan nilai Day's sales turn over Total Industri Sub Sektor Building Construction dari tahun 2014 sampai dengan 2019. Hasil rata-rata nilai Day's sales turn over PT. Indonesia Pondasi Raya Tbk selama lima tahun adalah 93,44 hari, sedangkan hasil rata-rata nilai Day's sales turn over Total Industri Sub Sektor Building Construction adalah 58,74 hari sehingga dapat disimpulkan bahwa nilai Day's sales turn over PT. Indonesia Pondasi Raya Tbk. berada posisi lebih tinggi dibandingkan dengan Total Industri Sub Sektor Building Construction.

Day's sales turn over dapat menunjukkan berapa lama rata-rata waktu yang dibutuhkan perusahaan untuk menyimpan persediaan mereka sebelum dijual, atau dapat juga dikatakan bahwa rasio ini dapat menunjukkan berapa lama rata-rata waktu yang dibutuhkan untuk menjual persediaan yang ada di perusahaan. Semakin kecil nilai Day's sales turn over ini artinya semakin cepat persediaan yang ada di perusahaan laku terjual atau semakin cepat perusahaan mampu menjual persediaan yang mereka punya sehingga akan memperkecil biaya penyimpanan persediaan dan memperkecil kemungkinan terjadinya kerusakan maupun penurunan kualitas dari persediaan karena terlalu lama disimpan di gudang. Oleh karena itu semakin kecil nilai Day's sales turn over pada perusahaan maka akan semakin baik.

Jadi, apabila dilihat dari nilai Day's sales turn overnya dapat disimpulkan bahwa PT. Indonesia Pondasi Raya Tbk. tidak lebih baik dibandingkan dengan Total Industri Sub Sektor Building Construction.

\section{e. Total Asset Turn Over}

Berikut adalah grafik Total asset turn over pada PT. Indonesia Pondasi Raya Tbk. dan Total Industri Sub Sektor Building Construction. 


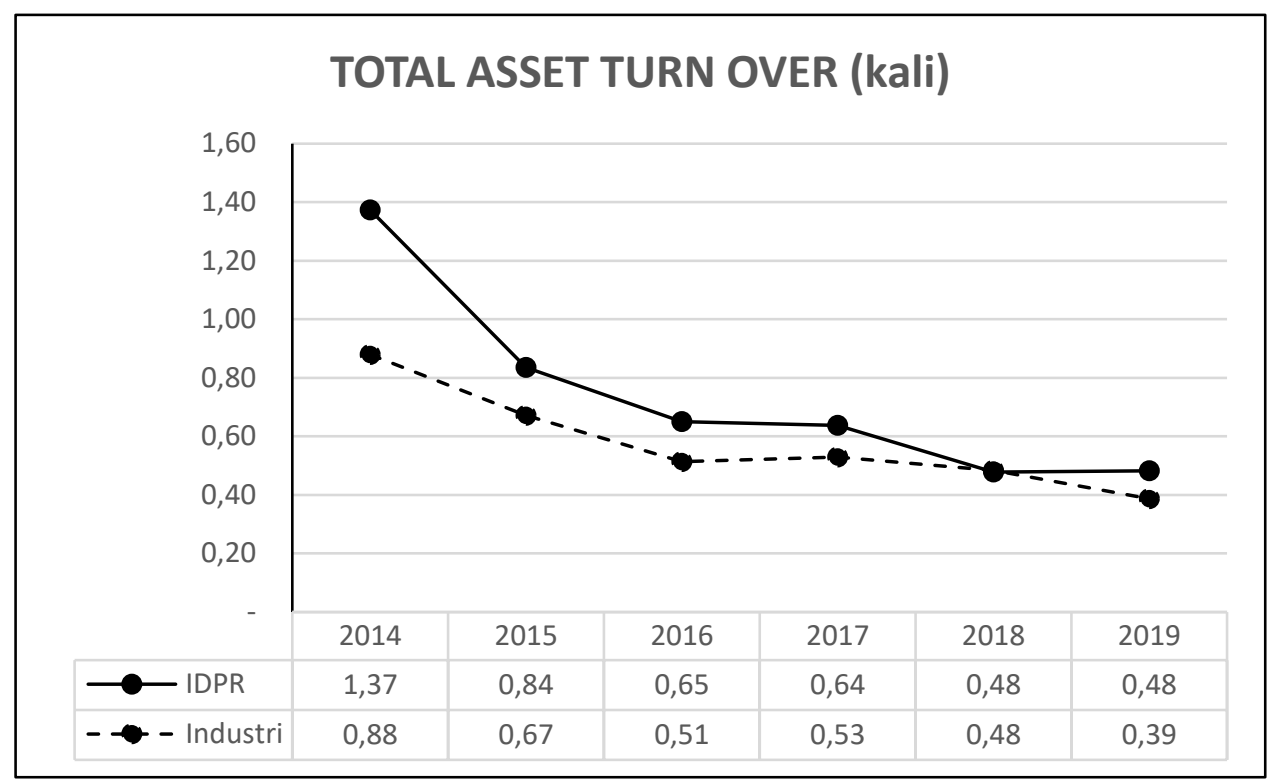

Grafik 11. Grafik Total asset turn over PT. Indonesia Pondasi Raya Tbk dan Total Industri Sub Sektor Building Construction

Berdasarkan grafik diatas kita dapat melihat nilai Total asset turn over PT. Indonesia Pondasi Raya Tbk. dan nilai Total asset turn over Total Industri Sub Sektor Building Construction dari tahun 2014 sampai dengan 2019. Hasil rata-rata nilai Total asset turn over PT. Indonesia Pondasi Raya Tbk selama lima tahun adalah 0,89 kali, sedangkan hasil ratarata nilai Total asset turn over Total Industri Sub Sektor Building Construction adalah 0,69 kali sehingga dapat disimpulkan bahwa nilai Total asset turn over PT. Indonesia Pondasi Raya Tbk berada posisi lebih tinggi dibandingkan dengan Total Industri Sub Sektor Building Construction.

Total asset turn over dapat menunjukkan kemampuan perusahaan dalam mengelola seluruh aset yang dimilikinya untuk menghasilkan penjualan. Semakin tinggi nilai Total asset turn over artinya semakin tinggi pula penjualan yang dilakukan oleh perusahaan dari hasil mengelola aset yang dimilikinya. Oleh karena itu, semakin tinggi nilai Total asset turn over pada perusahaan maka akan semakin baik.

Jadi, apabila dilihat dari nilai Total asset turn overnya dapat disimpulkan bahwa PT. Indonesia Pondasi Raya Tbk. lebih baik dibandingkan dengan Total Industri Sub Sektor Building Construction.

4. Rasio Profitabilitas

Analisis ini digunakan untuk menilai efisiensi penggunaan aset dan pengelolaan kinerja. Analisis ini ini terdiri dari Profit margin, return on asset (ROA) dan return on equity (ROE).

a. Profit margin

Berikut adalah grafik Profit margin pada PT. Indonesia Pondasi Raya Tbk. dan Total Industri Sub Sektor Building Construction. 


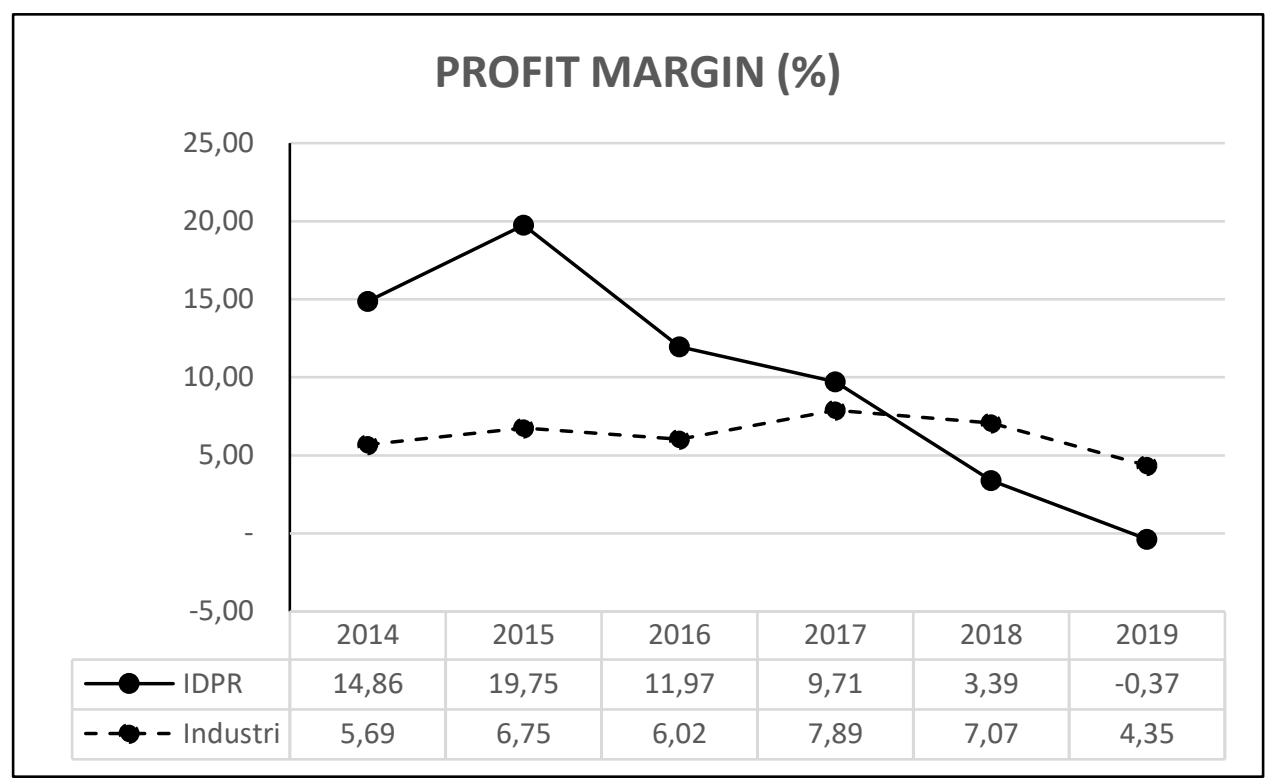

Grafik 12. Grafik Profit margin PT. Indonesia Pondasi Raya Tbk dan Total Industri Sub Sektor Building Construction

Berdasarkan grafik diatas kita dapat melihat nilai Profit margin PT. Indonesia Pondasi Raya Tbk. dan nilai Profit margin Total Industri Sub Sektor Building Construction dari tahun 2014 sampai dengan 2019. Hasil rata-rata nilai Profit margin PT. Indonesia Pondasi Raya Tbk selama lima tahun adalah $11,86 \%$, sedangkan hasil rata-rata nilai Profit margin Total Industri Sub Sektor Building Construction adalah 7,55 \% sehingga dapat disimpulkan bahwa nilai Profit margin PT. Indonesia Pondasi Raya Tbk berada posisi lebih tinggi dibandingkan dengan Total Industri Sub Sektor Building Construction.

Profit margin dapat menunjukkan seberapa besar keuntungan yang dapat diperoleh perusahaan dari aktivitas penjualan yang dilakukan, atau dapat juga dikatakan bahwa rasio ini dapat menunjukkan seberapa efektif dan efisiennya perusahaan dalam mengelola biaya dalam proses penjualan sehingga dapat memperoleh laba yang lebih tinggi dari hasil penjualan. Semakin tinggi nilai Profit margin artinya semakin tinggi pula laba yang dihasilkan perusahaan dari aktivitas penjualannya. Oleh karena itu, semakin tinggi nilai Profit margin pada perusahaan maka akan semakin baik.

Jadi, apabila dilihat dari nilai Profit marginnya dapat disimpulkan bahwa PT. Indonesia Pondasi Raya Tbk. lebih baik dibandingkan dengan Total Industri Sub Sektor Building Construction.

b. Return On Asset (ROA)

Berikut adalah grafik Return On Asset pada PT. Indonesia Pondasi Raya Tbk. dan Total Industri Sub Sektor Building Construction. 


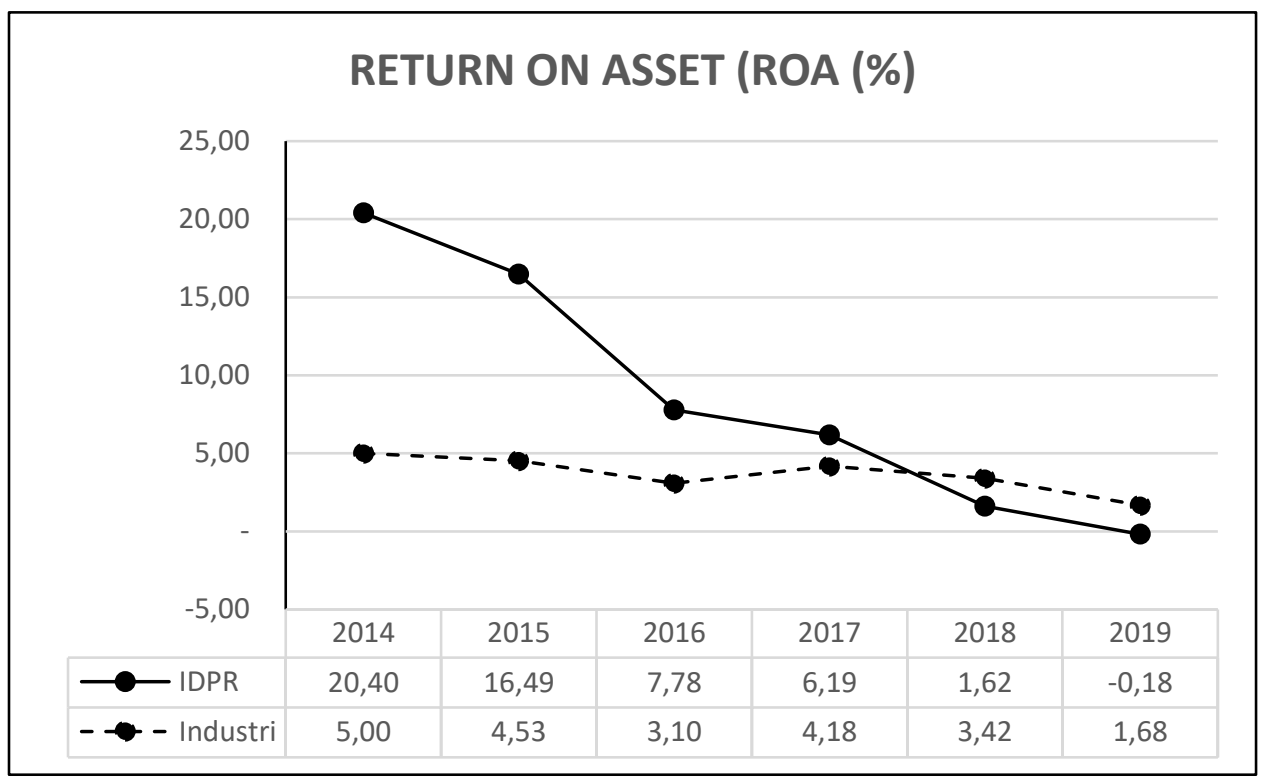

Grafik 13. Grafik Return On Asset PT. Indonesia Pondasi Raya Tbk dan Total Industri Sub Sektor Building Construction

Berdasarkan grafik diatas kita dapat melihat nilai Return On Asset PT. Indonesia Pondasi Raya Tbk. dan nilai Return On Asset Total Industri Sub Sektor Building Construction dari tahun 2014 sampai dengan 2019. Hasil rata-rata nilai Return On Asset PT. Indonesia Pondasi Raya Tbk selama lima tahun adalah 10,46 \%, sedangkan hasil ratarata nilai Return On Asset Total Industri Sub Sektor Building Construction adalah 4,38 \% sehingga dapat disimpulkan bahwa nilai Return On Asset PT. Indonesia Pondasi Raya Tbk berada posisi lebih tinggi dibandingkan dengan Total Industri Sub Sektor Building Construction.

Return On Asset dapat menunjukkan seberapa besar keuntungan yang dapat diperoleh atau dihasilkan peusahaan dari aset yang dimiliki perusahaan, atau dapat juga dikatakan bahwa rasio ini dapat menunjukkan seberapa efektif dan efisiennya perusahaan dalam mengelola aset yang dimilikinya sehingga dapat memperoleh laba yang lebih tinggi dengan aset tersebut. Semakin tinggi nilai Return On Asset artinya semakin tinggi pula laba yang dihasilkan perusahaan dari aset yang dimilikinya. Oleh karena itu, semakin tinggi nilai Return On Asset pada perusahaan maka akan semakin baik.

Jadi, apabila dilihat dari nilai Return On Assetnya dapat disimpulkan bahwa PT. Indonesia Pondasi Raya Tbk. lebih baik dibandingkan dengan Total Industri Sub Sektor Building Construction.

c. Return On Equity (ROE)

Berikut adalah grafik Return On Asset pada PT. Indonesia Pondasi Raya Tbk. dan Total Industri Sub Sektor Building Construction. 


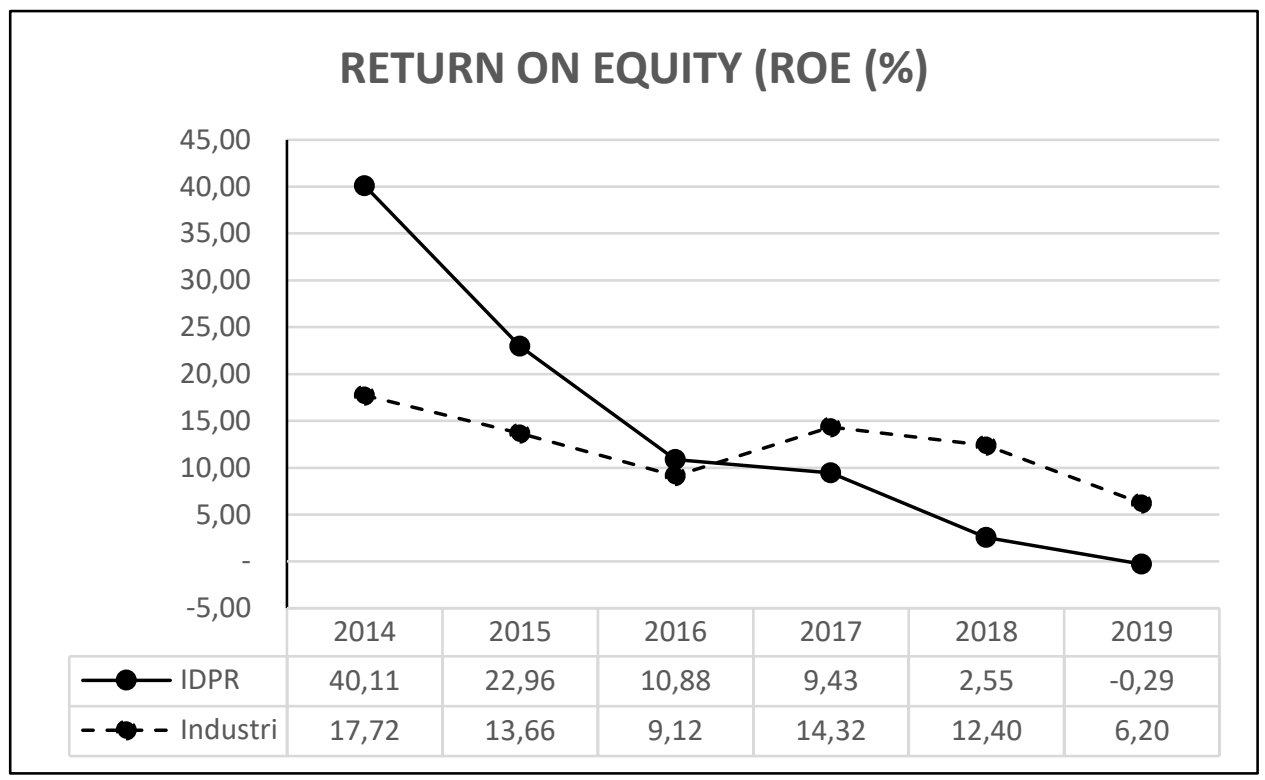

Grafik 14. Grafik Return On Equity PT. Indonesia Pondasi Raya Tbk dan Total Industri Sub Sektor Building Construction

Berdasarkan grafik diatas kita dapat melihat nilai Return On Equity PT. Indonesia Pondasi Raya Tbk. dan nilai Return On Equity Total Industri Sub Sektor Building Construction dari tahun 2014 sampai dengan 2019. Hasil rata-rata nilai Return On Equity PT. Indonesia Pondasi Raya Tbk selama lima tahun adalah 17,13 \%, sedangkan hasil ratarata nilai Return On Equity Total Industri Sub Sektor Building Construction adalah 14,68 $\%$ sehingga dapat disimpulkan bahwa nilai Return On Equity PT. Indonesia Pondasi Raya Tbk berada posisi lebih tinggi dibandingkan dengan Total Industri Sub Sektor Building Construction.

Return On Equity dapat menunjukkan seberapa besar keuntungan yang dapat diperoleh atau dihasilkan perusahaan dari ekuitas atau modal yang dimiliki oleh perusahaan, atau dapat juga dikatakan bahwa rasio ini dapat menunjukkan seberapa efektif dan efisiennya perusahaan dalam mengelola ekuitas atau modal yang dimilikinya sehingga dapat memperoleh laba yang lebih tinggi dengan ekuitas atau modal tersebut. Semakin tinggi nilai Return On Equity artinya semakin tinggi pula laba yang dihasilkan perusahaan dari ekuitas atau modal yang dimilikinya. Oleh karena itu, semakin tinggi nilai Return On Equity pada perusahaan maka akan semakin baik.

Jadi, apabila dilihat dari nilai Return On Equityrnya dapat disimpulkan bahwa PT. Indonesia Pondasi Raya Tbk. lebih baik dibandingkan dengan Total Industri Sub Sektor Building Construction. 


\section{Kesimpulan}

Berdasarkan Analisis Rasio yang dilakukan pada PT. Indonesia Pondasi Raya Tbk. dan Total Industri Sub Sektor Building Construction dapat diperoleh kesimpulan sebagai berikut :

1. Current Ratio PT. Indonesia Pondasi Raya Tbk. lebih baik dibandingkan dengan Total Industri Sub Sektor Building Construction.

2. Quick Ratio PT. Indonesia Pondasi Raya Tbk. lebih baik dibandingkan dengan Total Industri Sub Sektor Building Construction.

3. Total Debt Ratio PT. Indonesia Pondasi Raya Tbk. lebih baik dibandingkan dengan Total Industri Sub Sektor Building Construction.

4. Debt Equity Ratio PT. Indonesia Pondasi Raya Tbk. lebih baik dibandingkan dengan Total Industri Sub Sektor Building Construction.

5. Equity Multiplier Ratio PT. Indonesia Pondasi Raya Tbk. lebih baik dibandingkan dengan Total Industri Sub Sektor Building Construction.

6. Capital Structure PT. Indonesia Pondasi Raya Tbk. lebih baik dibandingkan dengan Total Industri Sub Sektor Building Construction.

7. Receivable Turn Over PT. Indonesia Pondasi Raya Tbk. lebih baik dibandingkan dengan Total Industri Sub Sektor Building Construction.

8. Day's Sales In Receivable PT. Indonesia Pondasi Raya Tbk. lebih baik dibandingkan dengan Total Industri Sub Sektor Building Construction.

9. Inventory Turn Over PT. Indonesia Pondasi Raya Tbk. tidak lebih baik dibandingkan dengan Total Industri Sub Sektor Building Construction.

10. Day's Sales Turn Over PT. Indonesia Pondasi Raya Tbk. tidak lebih baik dibandingkan dengan Total Industri Sub Sektor Building Construction.

11. Total Asset Turn Over Ratio PT. Indonesia Pondasi Raya Tbk. lebih baik dibandingkan dengan Total Industri Sub Sektor Building Construction.

12. Profit Margin PT. Indonesia Pondasi Raya Tbk. lebih baik dibandingkan dengan Total Industri Sub Sektor Building Construction.

13. Return On Asset PT. Indonesia Pondasi Raya Tbk. lebih baik dibandingkan dengan Total Industri Sub Sektor Building Construction.

14. Return On Equity Ratio PT. Indonesia Pondasi Raya Tbk. lebih baik dibandingkan dengan Total Industri Sub Sektor Building Construction.

Berdasakan Analisis Rasio secara keseluruhan dapat disimpulkan bahwa PT. Indonesia Pondasi Raya Tbk. lebih baik dibandingkan dengan Total Industri Sub Sektor Building Construction. 


\section{DAFTAR PUSTAKA}

Bursa Efek Indonesia. http://www.idx.co.id

Syintia Bahraini, Ratih Srie Intan Maisyuri. Analisis Komparatif Laporan Keuangan PT. Indofood CBP Sukses Makmur Tbk. dengan Total Industri Food and Beverage Periode 2014-2015.

Dedi Suhendro. Analisis Profitabilitas dan Likuiditas Untuk Menilai Kinerja Keuangan Pada PT. Siantar Top Tbk.

Muhammad Fadil Abu Bakar, Youlanda Hasan. Analisis Kinerja Keuangan Pada PT. PP (Persero) Tbk.

Munawir. 2014. Analisi Laporan Keuangan, Edisi Keempat, Cetakan ke-17. Yogyakarta: Liberty.

Kasmir. 2008. Analisis Laporan Keuangan. Jakarta: Rajawali Press.

Harahap, Sofyan Safr. 2010. Analisis Kritis Laporan Atas Laporan Keuangan. Jakarta: Raja Grafindo Persada.

Hery. 2015. Analisis Laporan Keuangan. CAPS. Yogyakarta. 